\title{
Nosocomial infections as one of the most important problems of the healthcare system
}

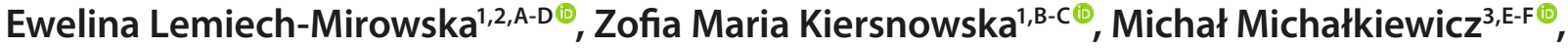 \\ Adam Depta ${ }^{4,5, \mathrm{~F}}$, Michał Marczak ${ }^{6, \mathrm{~F} \oplus}$ \\ 1 Project InterDoktorMen, Medical University of Lodz, Poland \\ ${ }^{2}$ Laboratory of Epidemiology, Military Institute of Hygiene and Epidemiology (WIHE), Warsaw, Poland \\ ${ }^{3}$ Institute of Environmental Engineering, Poznan University of Technology, Poland \\ ${ }^{4}$ Department of Management, University of Technology of Lodz, Poland \\ ${ }^{5}$ Department of Medical Insurance and Health Care Financing, Medical University of Lodz, Poland \\ ${ }^{6}$ Department of Management and Logistics in Health Care, Medical University of Lodz, Poland \\ A - Research concept and design, B - Collection and/or assembly of data, C - Data analysis and interpretation, \\ $D$ - Writing the article, E-Critical revision of the article, F- Final approval of article
}

Lemiech-Mirowska E, Kiersnowska ZM, Michałkiewicz M, Depta A, Marczak M. Nosocomial infections as one of the most important problems of the healthcare system. Ann Agric Environ Med. 2021; 28(3): 361-366. doi: 10.26444/aaem/122629

\section{Abstract}

Healthcare-associated infections (HAl) are commonly defined as adverse events resulting from the provision of healthcare. The reduction of risk arising from the spread of pathogenic microorganisms in the hospital environment is a considerable challenge in the context of the proper functioning of the medical services sector. The financial costs of hospitals resulting from HAl are a serious problem for the Polish healthcare system. The spread of strains with a high level of drug resistance in individual hospitals is associated with the local epidemiological situation. In 2015-2017, there was a high increase in the number of infections caused by New Delhi strains. The highest increase due to this strain occurred in Mazowieckie and Podlasie provinces. The dynamics of infection caused by New Delhi strains throughout Poland in 2015-2016 indicated an increase of $278.7 \%$. In 2017, the phenomenon of antibiotic abuse in all regions of Poland was $24 \%$ higher than the EU average. One of the reasons is the insufficient number of diagnostic tests ordered by both general practitioners and doctors representing hospital care. In 2016-2017, the average number of microbiological tests in diagnosing hospital infections performed annually within the entire territory of Poland was $50 \%$ lower than in European Union countries and the number recommended by WHO. Increased, and at the same time inappropriate antibiotic therapy led to a build-upof drug resistance among bacterial species of significant clinical importance. The current epidemiological situation imposes the necessity for constant HAl control and broadly understood rationalization of the guidelines of hospital antibiotic policy.

\section{Key words}

healthcare-associated infections (HAI), hospital infection control, costs of nosocomial infections

\section{INTRODUCTION}

According to data from the World Health Organization, healthcare-associated infections (HAIs) cause about 40,000 deaths per year, which translates into a level of nosocomial infections that rises as high as $25 \%$ in developing countries and $5-15 \%$ in developed countries $[1,2]$. In 2009, a team of experts gathered around the ECDC (European Centre for Disease Prevention and Control) provided definitions and criteria for diagnosing hospital infections, with the aim of unifying the system of identification and monitoring of new cases. The document prepared was based on the guidelines of HELICS/IPSE (Hospitals in Europe Link for Infection Control through Surveillance/Improving Patient Safety in Europe). In 1996, the Polish Society of Hospital Infections developed the First National Hospital Infections Registration Programme, which in 1998 was included by the CDC into the International Nosocomial Surveillance Programme for Emerging Antimicrobial Resistance (INSPEAR) [3].

The long-term global policy in the field of combating hospital infections shows that they reflect the level of quality of medical services, and that the strategy for minimizing

Address for correspondence: Zofia Maria Kiersnowska, InterDoktorMen, Medical University, Łódź, Poland

E-mail: zofiakiersnowska.p@gmail.com

Received: 10.02.2020; accepted: 20.05.2020; first published: 05.06.2020 them should involve comprehensive activities on many levels. Some of the directions of this policy include, among others, meticulous monitoring and registration of the current epidemiological situation, reliable microbiological diagnostics, adoption of appropriate procedures and comprehensive systems used by the Hospital Infections Control Team with the aim of actual minimization of the number of drug-resistant microorganisms, as well as a system of monitoring which antibiotics are used in outpatient and hospital care $[4,5]$. Effective control of hospital infections should become one of the priorities of the hospital's quality management system. Out of concern for the safety of patients and the quality of medical services provided, hospital infections should be included on the list of possible adverse events for which appropriate corrective and preventive actions are designed. In addition, hospitals should implement a Quality Management System based on PN-EN 15224: 2013 that refers to the revised international standard ISO 9001: 2015, as well as the Hospital Accreditation Programme, which have been developed by the Centre for Quality Assessment in Health Care [5-9]. Only the awareness of infections, of their existence and consequences, and knowledge about the causes, epidemiology and clinical symptoms, may result in their proper control and eradication.

According to the definition proposed by the $\mathrm{WHO}$, nosocomial infections are infections that have occurred 
48 - 72 hours after admission or discharge from hospital. For infections with a long incubation period, which include primarily hepatitis infection (HBV, HCV), acquired immunodeficiency virus (HIV) infection, and mycobacterium tuberculosis infection, an in-hospital origin ranging from two weeks to many years is assumed. Hospital infection can occur due to the action of a source of endogenous infection, i.e. microorganisms that are part of the natural flora or operation of the source of exogenous infection, i.e. microorganisms coming from outside (from inanimate environment - water, food, air or animate - another patient or carrier). Among the most common nosocomial infections are infections of the urinary and respiratory tracts, post-operative wounds, skin and connective tissue infections caused by violations of their continuity, as well as generalized infections, referred to as 'others' [10].

Situation in the Polish health care system. Detailed rules for carrying out epidemiological surveillance in health care units in Poland are based on the Act on preventing and fighting infections and infectious diseases in humans (Journal of Laws, Articles 1239 and 1495). This act regulates, among others, issues related to obligations arising from hospital infection control, the need to monitor and record hospital infections and alert factors, as well as the need to organize a hospital infection control team (ICT) and hospital infection control committee (HICC) and their tasks [6]. The supervision over infections is the primary task of every hospital and must be performed internally by its qualified staff at all levels, assisted by the hospital infection control team. Qualified employees within an infection control team and hospital infection control committee, should focus on the infections that pose the greatest and the most common threats to hospitalized patients; they should not only properly develop a system for preventing and combating nosocomial infections, but also provide such supervision that would be based on an active pathogen registration system due to the high sensitivity level of this method, which oscillates around 95\% according to the International Federation of Infection Control [11]. The system relies on a routine HAI verification process by an epidemiological nurse on the basis of nosocomial infection registration cards. The collected data is subject to detailed analysis by the Hospital Infection Control Team, which allows the implementation of corrective actions when irregularities are detected, and the development of so-called Emmerson's "epidemiological gold standard" [12]. The hospital infection control team should consist of an epidemiologist, epidemiological nurse, and laboratory diagnostician specializing in medical microbiology. The number of professionally-active doctors specializing in epidemiology does not meet the demand of the medical services sector. In mid-2017, their total number was only 556 specialists (fields included in the list: medical microbiology, epidemiology, epidemiology and hygiene) [13]. Figure 1 illustrates the situation of Poland in this aspect compared to other EU countries (last place in the ranking) [14]. A similar situation applies to nurses. According to data of the Supreme Council of Nurses and Midwives, in 2017 there were only 1,250 specialized employees in the field of epidemiological nursing, epidemiology, or hygiene and epidemiology.

In addition to staff shortages, there are also problems related to the infrastructure of many facilities, such as an insufficient number of rooms for isolation or cohortation of

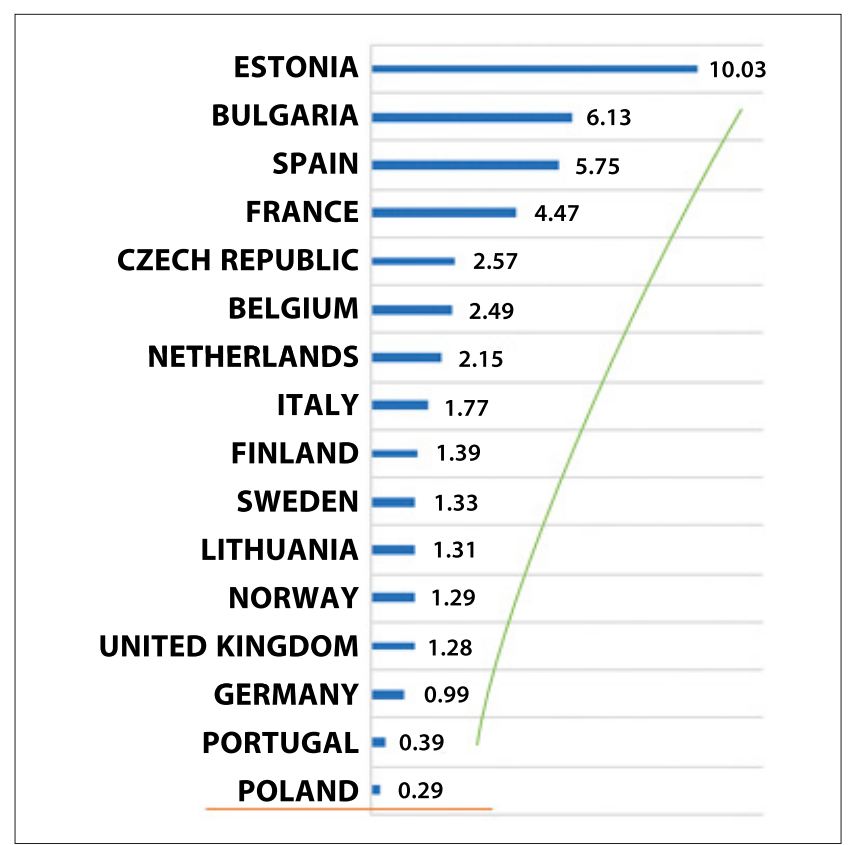

Figure 1. Number of practicing physicians specializing in medical microbiology in selected EU countries per 100,000 inhabitants

patients, shared bathrooms, equipment that does not meet current quality standards [15].

Another aspect overlooked in the context of the subprevention in the Polish healthcare system is the architecture of the hospital facility itself, which in many cases does not meet the needs related to the safety of hospitalization of patients, including the isolation of infected patients, and prevents the use of ergonomic solutions for the implementation of specific medical procedures. A report by the Supreme Audit Office indicates that the correct spatial organization of the health care unit designed from the outset to address specific needs and goals, makes it possible to reduce hospital infections and gives effective tools to minimize the risk in the event of an infectious outbreak. The correct functional and spatial layout consists not only of patient wards and treatment facilities, but also advanced technical installation systems, such as IT systems, mechanical ventilation, lighting, interior furnishings and the water and sewage network, all of which directly or indirectly determine the risk associated with the patient's stay in a medical facility. Safe use of the hospital infrastructure is also not possible without effective methods of decontamination of rooms, surfaces and equipment. The cause-and-effect analysis of a significant number of claims for damages filed against the largest health care units shows fundamental mistakes made in terms of implementation and, above all, control of hygiene and sanitary procedures. The non-ergonomic configuration of the work environment translates into the number of adverse events and paves the way for spreading hospital infections, hence the need for a comprehensive approach in the development of uniform engineering and architectural standards that should be applied at the design and control stage. The current threats and architectural needs of hospitals are not the same as the ones present years ago; therefore, it should be remembered that spatial standards must evolve and advance together with the changing situation in the Polish healthcare system. The most prominent example of this is the current coronavirus pandemic and a completely new approach in the field of 
triage, asepsis, and diagnostics, as well as the hospitalization and isolation of patients.

The basis for the implementation of effective solutions is interdisciplinary analysis based on a hard calculation of the risk of occurrence of an adverse event. Although Polish regulations define the minimum standards related to the architectural requirements of hospitals, they are only guidelines that address this issue at the surface level, and do not provide the appropriate tools to enforce the necessary improvements. System solutions must also specify the source of financing for all types of investments, in order that no glaring disproportion occurs between large facilities located in provincial cities and smaller county hospitals already struggling with problems at the level of basic healthcare services. In practice, this should mean equal opportunities to ensure the safety of patient hospitalization at all stages of the diagnostic and therapeutic process $[16,17]$

As stated in the findings of the Supreme Audit Office presented in the post-audit report "Infections in medicinal entities", the dynamics of the increase in the incidence rate of nosocomial infections requires detailed analysis and appropriate preventive measures. In the countries of the European Union, the problem of HAI affects $5-10 \%$ of patients undergoing hospitalization [18-20]. The study of point measurements of nosocomial infections shows that their prevalence in Polish hospitals does not exceed 7\% [21]. It is assumed that in Poland, infections associated with the provision of healthcare services reach 400,000 cases per year, which means $5 \%$ of all patients [17], with an annual number of hospitalizations of eight million [22]. It should be emphasized that this data is strongly underestimated, since many medical institutions do not carry out HAI control with due diligence. In practice, there is a huge discrepancy between daily hospital activities and the procedures and recommendations established by the national reference centres [23]. It is often problematic to prove that a hospital infection was contracted during a patient's stay in the hospital. Infectious microorganisms may come from the hospital environment due to, e.g. poorly sterilized medical equipment, contaminated surface (floor, door handles, chairs, sink knob), or from the hands of staff or visitors to the hospital; but the source of infection may also be bacterial flora colonized on the skin of a patient $[2,24]$. Risk of infection is also increased by factors directly related to the patient's condition, e.g. age, lowered immunity, nutritional status, coexistence of other diseases [25].

The lack of coordinated actions is due to the fact that in Poland there is still no designated entity that could serve as a national hospital infections control cenre. The National Antibiotic Protection Program (NPOA), established in 2004, was a response to the requirements set by Decision No. 2119/98/EC of the European Parliament and of the Council as a step towards creating an Early Warning Response System (EWRS) of the risks associated with HAI [26]. The world literature and the WHO state that the phenomenon of increasing drug resistance is one of the main factors posing a high risk of threat to public health security on a worldwide scale [4, 27-29]. An effective epidemiological surveillance system is able to reduce the risk of HAI by $55-70 \%$ [30]. An infection control programme should be based on the continuous training of medical staff and the effective prevention and efficient monitoring of all HAI cases [31]. The report of the Supreme Audit Office indicates an urgent need for system changes because procedures related to the prevention of nosocomial infections are ineffective, as evidenced by the example of the rapid spread of the Klebsiella pneumoniae NDM-1 bacterium belonging to the ST11 pandemic clone that is resistant to almost all known antimicrobial drugs [32]. Table 1 presents the dynamics of infections caused by New Delhi strains in Poland in 2015, 2016, and in the first quarter of 2017 [17].

Table 1. Data from 16 provinces regarding infections caused by Klebsiella pneumoniae NDM-1

\begin{tabular}{|c|c|c|c|}
\hline \multirow{2}{*}{ Province } & \multicolumn{3}{|c|}{ Number of infected patients } \\
\hline & 2015 & 2016 & 2017 (1st quarter) \\
\hline Mazowieckie & 404 & 1,316 & 1,037 \\
\hline Łódzkie & - & 9 & 22 \\
\hline Podlaskie & 6 & 253 & 312 \\
\hline Warmińsko-Mazurskie & 4 & 14 & 36 \\
\hline Pomorskie & - & 3 & 6 \\
\hline Zachodnio-Pomorskie & 1 & 15 & 13 \\
\hline Kujawsko-Pomorskie & 2 & 11 & 8 \\
\hline Lubuskie & 11 & - & - \\
\hline Dolnośląskie & 1 & 19 & 14 \\
\hline Opolskie & - & - & - \\
\hline Śląskie & 1 & 17 & 6 \\
\hline Małopolskie & - & 4 & 3 \\
\hline Świętokrzyskie & - & 6 & 14 \\
\hline Lubelskie & - & 5 & 11 \\
\hline Podkarpackie & - & - & - \\
\hline Wielkopolskie & 14 & 9 & 4 \\
\hline Total & 444 & 1,681 & 1,486 \\
\hline
\end{tabular}

Most infections caused by Klebsiella pneumoniae New Delhi were recorded in the Mazowieckie and Podlaskie provinces. In two other provinces (Opolskie and Podkarpackie) no case of a patient infected with the NDM-1 strain was registered which, however, does not mean that no such problem exists. Klebsiella pneumoniae belongs to the Gram-negative bacilli of the Enterobacteriaceae family, first diagnosed in 1882 in Germany as the cause of pneumonia. It is estimated that between $3-5 \%$ of healthy people and $11 \%$ of people treated in hospital, are carriers of this bacterium. Infection can be by direct contact with the carrier or by the droplet route. It can also occur after delivery, but this bacterium is not dangerous for healthy, full-term newborns. The situation is much more serious in the case of premature babies [33]. According to the European Union Epidemiological Reports, pneumonia caused in hospital by K. pneumoniae constitutes, on average, about $10 \%$ of all hospital infections in EU countries. Hospital urinary tract infections with this microorganism, on average $8.8 \%$, and blood infections caused by K. pneumoniae averaged $8.7 \%$ of all nosocomial infections in the European Union. In Poland, according to the same report, the percentage of multi-resistant Klebsiella pneumoniae strains is between $25-50 \%$, which is one of the highest results in Europe; for comparison, this percentage in Sweden is about 2\% [33]. 
The spread of strains with high levels of drug resistance in individual hospitals is associated with a local epidemiological situation. The selection of resistant strains is fostered by overuse of antibiotics in outpatient care without explicit clinical indications or their prescription in the case of infections of viral etiology [34]. A constant practice indicated by family doctors as one of the main reasons for this is the pressure from patients who often force a clinician to administer an antimicrobial drug [35]. Another issue is not following the recommendations related to their intake [36]. Premature discontinuation of treatment or the use of too low doses inhibits the elimination of the pathogen and makes it difficult to reach a therapeutic level of a drug. This results in the frequent recurrence of infections, and also gives bacteria the necessary space to develop resistance mechanisms, and allows horizontal gene transfer between unrelated species [37-41]. The comparison of daily antibiotic consumption in individual provinces in Poland, divided into open and closed healthcare, is summarized in Table 2 [42].

Table 2. Consumption of antibiotics in individual provinces in DDD in 2017 in open and closed health care.

\begin{tabular}{|c|c|c|}
\hline \multirow{2}{*}{ Province } & Open healthcare & Closed healthcare \\
\hline & \multicolumn{2}{|c|}{ [defined daily dose per 1,000 inhabitants] } \\
\hline Mazowieckie & 25.64 & 2.21 \\
\hline Łódzkie & 30.58 & 2.63 \\
\hline Podlaskie & 24.93 & 1.69 \\
\hline Warmińsko-mazurskie & 23.97 & 1.76 \\
\hline Pomorskie & 25.73 & 1.76 \\
\hline Zachodniopomorskie & 25.14 & 1.71 \\
\hline Kujawsko-pomorskie & 24.97 & 1.75 \\
\hline Lubuskie & 25.88 & 1.49 \\
\hline Dolnośląskie & 24.74 & 1.69 \\
\hline Opolskie & 22.56 & 1.50 \\
\hline Śląskie & 26.05 & 1.75 \\
\hline Małopolskie & 25.68 & 1.64 \\
\hline Świętokrzyskie & 26.05 & 1.51 \\
\hline Lubelskie & 25.43 & 1.71 \\
\hline Podkarpackie & 23.97 & 1.35 \\
\hline \multirow[t]{4}{*}{ Wielkopolskie } & 26.07 & 1.38 \\
\hline & \multicolumn{2}{|c|}{ National average adopted in reports } \\
\hline & 27.0 & 1.79 \\
\hline & UE/EOG Countries 21.8 & $\begin{array}{l}\approx 24 \% \text { lower } \\
\text { drug consumption }\end{array}$ \\
\hline
\end{tabular}

In Poland, there is no national system for monitoring the use of antibiotics in outpatient and hospital care, which makes it impossible to obtain real data in this field and carry out a realistic assessment of the scale of the abuse of antibiotics. The presented summary indicates s a disturbing trend that involves all regions of the country in terms of the use of antibacterial drugs in open healthcare, which is $24 \%$ higher than the EU average. One of the reasons is the insufficient number of diagnostic tests ordered by both general practitioners and clinicians representing inpatient care. When monitoring hospital infections, the microbiology laboratory is one of the most important elements in the supervision and treatment process. Quick identification and determination of the antibiogram for an isolated microorganism is the basis for optimizing antibiotic therapy and ensuring the highest quality of medical services [43]. It is also especially invaluable in the case of epidemiological outbreaks. In terms of the number of diagnostic tests performed, Poland is still far behind when compared to other European Union countries. Table 3 summarizes the average number of microbiological tests performed.

Table 3. Use of microbiological tests for diagnosis of nosocomial infections

\begin{tabular}{lll}
\hline & \multicolumn{2}{c}{ Average number of microbiological tests } \\
Wer vear per bed \\
\hline WHO recommendations & 50 \\
\hline UE Countries & 54 \\
\hline Poland & $(2016)$ & 22.4 \\
\cline { 2 - 3 } & (2017) & 24.5 \\
50\% below the \\
recommended standard
\end{tabular}

Cross-infections transferred by hands account for $2-40 \%$ of all nosocomial infections. Although the use of antibiotics and immunosuppressive drugs makes it possible to save the health and lives of patients, they often also cause increasing resistance of hospital pathogens. In order to prevent infections, maintaining a high standard hygiene among medical staff, nurses in particular, is of prime importance. Hygiene, disinfection, asepsis, and work organization procedures in hospitals must be well-known, understood and implemented in accordance with their knowledge. The established hospital procedures for hygiene, disinfection, aseptic techniques and work organization must also be wellknown, understood and implemented in accordance with the acquired knowledge. Nurses demonstrate a diversified knowledge of hospital infections, but this knowledge also goes hand-in-hand with the level of education and additional professional qualifications [4, 44]. An equally important aspect is the sterility of surgical equipment and inctruments, which directly depends on maintaining the correct handling of materials prior to sterilization, a proper sterilization process, and respecting the rules of transport and storage. Improper decontamination can lead not only to medical, organizational and financial consequences, but also to legal issues. Contaminated surgical and gynaecological instruments, needles, syringes, catheters, dressings, endoscopes, respirators, etc. may become a source of hospital infections [45].

Costs of nosocomial infections. The most measurable effects resulting from deficiencies arising in the field of HAI include the increase in costs incurred by hospitals as a result of prolonged hospitalization of patients [46, 47]. Hospitals are reluctant to provide information on financial expenses concerning individual medical procedures, which means that all calculations are subject to a margin of error [48]. Table 4 shows a cumulative comparison of the average costs of treatment divided into two groups: non-infected patients and patients infected with drug-resistant bacteria [20]. Data provided by provincial branches of the Polish National Health Fund (NFZ).

The highest expenditures related to the prolonged hospitalization of the patient as a result of HAI treatment 
Table 4. Average cost of treatment of hospitalized patients for 2016,2017 and the first half of 2018

\begin{tabular}{llc}
\hline \multirow{2}{*}{ Province } & \multicolumn{2}{c}{ Average cost of treatment [tys. zł] } \\
\cline { 2 - 3 } Mazowieckie & Non-infected patients & $\begin{array}{c}\text { Patients infected with } \\
\text { drug-resistant bacteria }\end{array}$ \\
\hline tódzkie & 2.6 & 6.2 \\
\hline Podlaskie & 3.0 & 3.7 \\
\hline Warmińsko-Mazurskie & 3.0 & 4.6 \\
\hline Pomorskie & 2.4 & 3.9 \\
\hline Zachodnio-Pomorskie & 2.3 & 5.2 \\
\hline Kujawsko-Pomorskie & 2.3 & 5.3 \\
\hline Lubuskie & 2.9 & 5.7 \\
\hline Dolnośląskie & 2.2 & 5.2 \\
\hline Opolskie & 2.4 & 5.5 \\
\hline Śląskie & 2.0 & 5.1 \\
\hline Małopolskie & 2.9 & 5.2 \\
\hline Świętokrzyskie & $\mathbf{2 . 1}$ & 4.6 \\
\hline Lubelskie & 2.0 & 4.0 \\
\hline Podkarpackie & 2.4 & 4.0 \\
\hline Wielkopolskie & 2.2 & 4.0 \\
\hline & & 4.4 \\
\hline
\end{tabular}

HAl increase in investment by $95 \%$

were recorded in the Mazowieckie province where the average cost of treatment of a patient from this group was 3.6 thousand PLN higher in the analyzed time period, compared to a non-infected patient (increase of 138.5\%). In the Łódzkie province, the cost difference in both groups was the lowest and amounted to 0.7 thousand PLN, i.e. $23.3 \%$. After analyzing the above register with the data contained in Table 1, some correlations can be observed at the regional level related to the incidence rate of multi-resistant strains and therapeutic difficulties. The spread of MDR (multidrugresistant) strains in the hospital environment carries a high risk of severe complications, including sepsis. Intensive Care Units (ICUs) accumulate over $25 \%$ of all HAI cases [49]. The specificity of ICUs is associated with an increased supply of antibacterial drugs compared to other departments, which results from the type of clinical cases that undergo treatment in these units [50]. Taking into account that intensive care units are places where patients in the most severe health condition are present, this incurs a great risk of hospital infections, which ar - 10 times more frequent there than in other inpatient wards. Therefore, analyses are performed of microbial species and drug susceptibility phenotypes in order to prevent and treat infections as effectively as possible. A study carried out in 1,265 intensive care units in 75 countries worldwide, demonstrated out that the most common pathogens causing infection were Gram-negative microorganisms (62\%), followed by Gram-positive bacteria (47\%), and $17 \%$ were fungal infections. The prevalence of hospital infections in Poland is similar to that in other European medical centres $[1,3]$.
Research conducted as part of the National Antibiotic Protection Programme (NPOA) showed that the risk associated with nosocomial blood infection affects nearly $6.5 \%$ of patients hospitalized in ICU departments [50]. In Poland, 2015-2017 (first half of the year), the number of patients hospitalized due to sepsis was 60,381 , of whom the number of hospitalized adults was 51,537 and the number of hospitalized children $-8,844$. With regard to the number of sepsis cases, the Mazowieckie province is in the lead - 9,550 and 1,749 adults and children, respectively. It is not without significance that this province is in the central part of the country in which a large group of medical facilities with high reference are located. A large number of cases was also recorded in the Pomeranian province - 5,533 adults, and the Śląskie province - 5,034 and 960 adults, children, respecyively, and the Kuyavian-Pomeranian province - 988 children. The smallest number of cases hospitalized for sepsis was recorded in Lubuskie province - 1,191 adults, Opolskie province - 127 children, Podlaskie province - 1,315 and 182 adults, children, respectively [50].

According to the NPOA, financial outlays in Poland for the diagnostic and therapeutic process of patients with sepsis for 2015 - 2017 (first half) for patients over 18 years of age, amounted to 449,770.1 thousand PLN, and for patients under 18 years of age, amounted to 63,611 thousand PLN. The number of cases increases year by year and thus also the cost of treatment. Comparing the years 2015 and 2016, the value of medical services provided for patients over 18 years of age increased by $15.9 \%$, and in patients under 18 years of age increased by $4.7 \%$ [50]. According to the data of the Polish Society of Hospital Infections (Polskie Towarzystwo Zakażeń Szpitalnych - PTZS), - 10 people per 100 hospitalized patients may become infected in a Polish hospital. These statistics also indicate that reducing hospital infections by at least $1 \%$ can reduce treatment costs by as much as $7-10 \%$ [51].

The supervision of nosocomial infections should be performed in such a way as to make the stay of hospitalized patients visibly shorter, the hospital's financial outlays visibly lower, and the level of safety of hospitalized patients increased. Additionally, in order to reduce HAI and hospital mortality, the following should be introduced as mandatory: audits, internal controls, staff education and activities affecting their behavior, planned team work and performance evaluation [18].

\section{CONCLUSION}

Analysis of data on the epidemiological situation in Polish units of inpatient care clearly indicates the need to take decisive and coordinated action at the level of State administration in order to reduce the risk of adverse events, such as hospital-acquired infections. There is a significant correlation between ineffective prevention and control of nosocomial infections and an increase in the direct and indirect costs incurred by medical facilities. The most important factors that negatively affect the health care system include, staff shortages, inconsistent hospital policy regarding monitoring of hospital infections, non-compliance with hygiene and hand disinfection by medical staff, abuse of antibiotics, especially by outpatient clinics, horizontal gene transfer also between unrelated species and the spread of multidrug-resistant strains in a hospital environment. In 
accordance with the recommendations developed by the European Commission and the World Health Organization (WHO), the priority issue is to establish in Poland a national reference centre for the prevention and control of nosocomial infections, and to produce, under the auspices of the Ministry of Health, recommendations on HAI control which would constitute a national reference document [52-54].

\section{REFERENCES}

1. Larypoor M, Frsad S. Evaluation of nosocomial infections in one of hospitals of Qom, 2008. Iran J Med Microbiol. Persian. 2011; 5(3): 7-17.

2. Olise CC, Simon-Oke IA, et al. Fomites: Possible vehicle of nosocomial infections. J Pub Health Catalog. 2018; 1(1): 16-16.

3. Dobrosielska-Matusik KM, Pilecki W. Problem szpitalnych zakażeń krwi u pacjentów hospitalizowanych na oddziałach intensywnej terapii. Piel Zdr Publ. 2019; 9(1): 63-70.

4. Kiersnowska Z, Lemiech-Mirowska E, Ginter-Kramarczyk D Kruszelnicka I, Michałkiewicz M, Marczak M. Problems of Clostridium difficile infection (CDI) in Polish healthcare units. Ann Agric Environ Med. 2020. doi:10.26444/aaem/119321.

5. Bulanda M, Burzyńska B, Ciążyński M, Deptuła A, Dębicka B, Dubiel $\mathrm{G}$, at. al. System kontroli zakażeń związanych z opieką zdrowotną w Polsce. Stowarzyszenie Epidemiologii Szpitalnej. 2016.

6. Dudzik-Urbaniak E, Kutaj-Wąsikowska H, Kutryba B, Piotrowski M. Program Akredytacji - Szpitale, zestaw standardów; 2016

7. Dz.U. 2019, poz. 1239. Obwieszczenie Marszałka Sejmu Rzeczypospolitej Polskiej z dnia 6 czerwca 2019 r. w sprawie ogłoszenia jednolitego tekstu ustawy o zapobieganiu oraz zwalczaniu zakażeń i chorób zakaźnych u ludzi.

8. PN EN 15244:2013. Usługi sektora ochrony zdrowia - Systemy zarzadzania jakością - Wymagania oparte na EN ISO 9001:2015.

9. ISO 9001:2015 System Zarządzania Jakością - wymagania

10. Osińska M, Rysiak E, Zaręba R, Worona P, Kazberuk A, Prokop I, Celińska-Janowicz K, Zaręba I. Zakażenia szpitalne w aspekcie prawnym. Anestezjologia i Ratownictwo 2018; 12: 353-356.

11. Dziewa AM, Ksykiewicz-Dorota A. Methods of monitoring and registration of hospital infections. Hygeia Public Health 2012; 47(1) 56-63.

12. Sadowska M. Cause-and effectrelationship as the premise of provider'sliability for hospital-acquiredinfection. Studia Prawnicze KUL. 2017:3,71,107-120.

13. Centralny Rejestr Lekarzy - Naczelna Izba Lekarska. https://www. nil.org.pl/rejestr...

14. Najwyższa Izba Kontroli. Zakażenia w szpitalach poważnym problemem. 2018

15. ECDC. Europa. EU. Point prevalence survey of healthcare-associated infections and antimicrobial use in European acute care hospitals 2011-2012.

16. Janowicz R. Ograniczenie zakażeń szpitalnych z wykorzystaniem środków architektonicznych. Wydawnictwo Wydziału Architektury Politechniki Gdańskiej, pp. 209. ISBN. 2019; 978-83-64333-27-9.

17. Najwyższa Izba Kontroli. Zakażenia w podmiotach leczniczych. Lata 2016-2017 (I półrocze).

18. Elliott C. Justiz-Vaillant A. Nosocomial Infections: A 360-degree Review. Int Biol Biomed J. 2018; 4(2): 72-81.

19. Stanek J, Zyzik R. Prevention of healthcare associated infections behavioural perspective. Hygeia Public Health. 2018;53 (4): 333-339.

20. Umar D, Basheer B, Husain A, et al. Evaluation of bacterial contamination in a clinical environment. J Int Oral Health 2015; 7(1): $53-5$

21. Deptuła A. at. all. Raport z badań punktowych HAI\&AU w Polsce, Warszawa 2016.

22. Główny Urzad Statystyczny Zdrowie i Ochrona Zdrowia w 2014 roku. Warszawa 2015.

23. Haque M, Sartelli M, McKimm J, Bakar MA. Health care-associated infections - an overview. Infect Drug Resistance. 2018; 11: 2321-2333.

24. Farahani A, Mohajeri P, Soltani S, Getso MI, Khatib M, Dastranj $M$. Investigation of bio-air contamination in some hospitals of Kermanshah, Iran. Adv Human Biol. 2019;9(1):65. doi:10.4103/aihb. aihb_49_18.

25. Sadowska M. Cause-and effectrelationship as the premise of provider'sliability for hospital-acquiredinfection). Studia Prawnicze KUL, 2017. 3, 71, 107-120.

26. Wilson AP, Livermore DM, Otter JA, et al. Prevention and control of multi-drug- -resistant Gram-negative bacteria: recommendations from a Joint Working Party. J Hosp Infect. 2016; 92(Suppl. 1): S1- S44.

27. World Health Organization. Health care-associated infections. Fact sheet. WHO. www.who.int/gpsc/country_work/..
28. Tolera M, Degu A, Dheresa M, Marami D. Bacterial Nosocomial Infections and Antimicrobial Susceptibility Pattern among Patients Admitted at Hiwot Fana Specialized University Hospital, Eastern Ethiopia. Hindawi Adv Med. 2018, Article ID 2127814,7. DOI:0.1155/2018/2127814

29. Suetens C, Latour K, Kärki T, Ricchizzi E, Kinross P, Moro ML, et al. Prevalence of healthcare-associated infections, estimated incidence and composite antimicrobial resistance index in acute care hospitals and long-term care facilities: results from two European point prevalence surveys, 2016 to 2017. Euro Surveill. 2018; 23(46): pii=1800516. DOI:10.2807/1560-7917.ES.2018.23.46.1800516

30. Craig A, et al. Estimating the proportion of healthcare-associated infections that are reasonably preventable and the related mortality and costs, Infect Control Hosp Epidemiol. 2011; 32: 101-14.

31. Zimlichman E, Henderson D, Tamir O, et al. Health care-associated infections: A meta-analysis of costs and financial impact on the US health care system. JAMA Intern Med. 2013; 173: 2039-46.

32. Baraniak A, Izdepski R, Fiett J, Gawryszewska I, Bojarska K, Herda M, Literacka E. NDM-producing Enterobacteriaceae in Poland, 2012-14: inter-regional outbreak of Klebsiella pneumoniae ST11 and sporadic cases, J Animicrob Chmother. 2016; 71: 85-91.

33. Czekaj T, Ciszewski M. Klebsiella pneumoniae NDM - nowa superbakteria. Med Rodz. 2015; 1: 23-27.

34. Wojkowska-Mach J, Godman B, Glassman, et al. Antibiotic consumption and antimicrobial resistance in Poland; findings and implications, Antimicrob Resist Infect Control. 2018; 7: 136.

35. Centers for Disease Control and Prevention. Antibiotic resistance threats in the United States. 2013: 11-21.

36. Leclercq R. Safeguarding future antimicrobal options: strategies to minimize resistance Clin Microbiol Infect. 2001; 7(3): 18-23.

37. Markiewicz Z, Kwiatkowski Z. Bakterie, antybiotyki, lekooporność Wyd. Naukowe PWN Warszawa 2006.

38. Sadkowska-Todys M, Zieliński A, Czarkowski MP. Infectious diseases in Poland in 2017. Prz Epidemiol. 2019; 73(2):135-15.

39. BAJ J, Markiewicz Z. Biologia molekularna bakterii Wyd. Naukowe PWN Warszawa 2006.

40. Cooper RM, Tsimring L, Hasty J. Inter-species population dynamics enhance microbial horizontal gene transfer and spread of antibiotic resistance. eLife. 2017; 6: e25950. Published online 2017 Nov 1. doi: $10.7554 /$ eLife. 25950

41. Kiersnowska Z, Lemiech-Mirowska E, et al. Sytuacja epidemiologiczna w jednostkach ochrony zdrowia, Badania i rozwój Młodych Naukowców w Polsce 2019; 2:13-19.

42. Naczelna Izba Kontroli. Zakażenia w szpitalach poważnym problemem. 2018.

43. Nazir A, Kadri SM. An overview of hospital acquired infections and the role of the microbiology laboratory. Int J Res Med Sci. 2014; 2(1): 21- 27.

44. Chwedoruk M, Gotlib J. Assessment of knowledge of nurses in surgical departments on hospital infections spread by the contact route. Med Og Nauk Zdr. 2014; 20(2): 192-198.

45. Szymańska-Pomorska G, Pytel A, Smolińska B. Hospitalinfections as a modern hospitalepidemiological problem. Decontamination and rules of medical equipment storage. Piel Zdr Publ. 2017;7(2): 149-152. DOI:10.17219/pzp/75215.

46. Yu Lü, Min Hong Cai, Jian Cheng J, et al. A multi-center nested case-control study on hospitalization costs and length of stay due to healthcare-associated infection. Antimicrob Resist Infect Control. 2018; 7: 99.

47. Khan ID, Basu A, Kiran S, Trivedi S, Pandit P, Anupam Ch. DeviceAssociated Healthcare-Associated Infections (DA-HAI) and the caveat of multiresistance in a multidisciplinary intensive care unit. Med J Armed Forces India. 2017; 73(3): 222-231.

48. Kołpa M, Wałaszek M, Różańska A, Wolak Z, Wójkowska-Mach J. Hospital-Wide Surveillance of Healthcare-Associated Infections as a Source of Information about Specific Hospital Needs. A 5-Year Observation in a Multiprofile Provincial Hospital in the South of Poland. Int J Environ Res Public Health. 2018 Sep; 15(9): 1956.

49. Maciejewski D, Misiewska-Kaczur A. Zakażenia w oddziałach intensywnej terapii. In: Zakażenia szpitalne. Ed. D. Dzierżanowska. Media Press, Bielsko-Biała 2008: 249-265.

50. Sprawozdanie $\mathrm{z}$ realizacji Narodowego Programu Ochrony Antybiotyków 2012. www.antybiotyki.edu.pl

51. Sołtys-Bolibrzuch K. Prevention of nosocomial infections. sisyphean work of an epidemiological nurse. Zakażenia XXI wieku 2019;2(1):3339. DOI: 10.31350/zakazenia/2019/1/Z2019002.

52. Zarb P, Coignard B, Griskeviciene J, et al. The European Centre for Disease Prevention and Control (ECDC) pilot point prevalence survey of healthcare-associated infections and antimicrobial use. Euro Surveill. 2012;17.

53. Pittet D, et al. Considerations for a WHO European strategy on healthcare-associated infection, surveillance, and control. Lancet Infect Dis. 2005;5:242-5

54. Duke MT, Kinney S, Daley AJ, Soenarto Y. Reducing hospital-acquired infections and improving the rational use of antibiotics in a developing country: an effectiveness study. Arch Dis Child. 2015; 100(5): 454-459. 